\title{
Pengaruh Loving Tauch Baby Massage Terhadap Pola Tidur Batita
}

\author{
Kata Kunci \\ Loving touch baby \\ massage, \\ Pola tidur
}

\author{
Rusiana Sri Haryanti ${ }^{1^{*}}$, Tria Puspita Sari ${ }^{2}$,Wiwik Puspita Dewi ${ }^{3}$ \\ ${ }^{1,2,3}$ Prodi D III Kebidanan, ITS PKU Muhammadiyah Surakarta \\ *Email: rusianamolyn@gmail.com
}

\begin{abstract}
Abstrak
Masa emas pertumbuhan dan perkembangan terjadi pada masa batita. Salah satu faktor yang mempengaruhi tumbuh kembang anak adalah saat tidur dan istirahat, karena pada saat anak tidur pertumbuhan otaknya mencapai pertumbuhan yang optimal. Tidur merupakan prioritas utama bagi bayi, karena pada saat inilah terjadi repair neuro brain dan kurang lebih $75 \%$ hormon pertumbuhan diproduksi. Tercapainya pertumbuhan dan perkem-bangan anak yang optimal merupakan hasil interaksi berbagai faktor yang saling berkaitan, yantiu faktor genetik, lingkungan, perilaku, rangsangan atau stimulasi yang bermanfaat. Salah satu stimulasi berupa taktil adalah pemijatan pada anak (baby massage). Pijat juga dapat bermanfaat untuk memenuh waktu tidur dan perkembangan bayi. Bayi yang dipijat akan dapat tidur dengan lelap, Tujuan penelitian ini adalah untuk mengetahui pengaruh loving touch baby massage terhadap pola tidur batita. Metode penelitian ini adalah cross sectional. Penelitian dilakukan di baby smile karanganyar, jumlah sampel 50 batita dengan teknik purposive sampling. Pengumpulan data menggunakan koesioner tentang massage dan pola tidur. Analisis data menggunakan Wilcoxon dan Mc Nemar didapatkan hasil nilai $p=0,000$. Hasil penelitian didapatkan bahwa batita setelah dilakukan massage mengalami perubahan pola tidur yang lebih baik dari pada sebelum dilakukan massage. Kesimpulan penelitian ini ada pengaruh loving touch baby massage terhadap pola tidur batita.
\end{abstract}

\section{The Effect of Loving Touch Baby Massage on Toddler Sleep Patterns}

\author{
Key Words: \\ Loving touch baby \\ massage, \\ Sleep patterns
}

\begin{abstract}
The golden period of growth and development occurs during the toddler. One of the factors that influence a child's growth and development is during sleep and rest, because when the child is sleeping his brain growth reaches optimal growth. Sleep is a top priority for babies, because in this time neuro brain repair occurs and approximately $75 \%$ of growth hormone is produced. The achieving optimal growth and development of children is the result of the interaction of various interrelated factors, which are genetic, environmental, behavioral, stimulating or stimulating factors that are beneficial. One of the stimulations in the form of tactile is massage in children (baby massage). Massage can also be useful for full sleep and baby development. A baby who is massaged will be able to sleep soundly, The purpose of this study was to determine the effect of loving touch baby massage on toddler sleep patterns. This research method was cross sectional. The study was conducted in Karanganyar baby smile, the number of samples was 50 toddlers with purposive sampling technique. The data collection used questionnaires about massage and sleep patterns. The data analysis using Wilcoxon and Mc Nemar obtained the value of $p=0,000$. The results showed that toddlers after a massage experience changes in sleep patterns more than before massage. The conclusion of this study There is the influence of loving touch baby massage on toddler sleep patterns.
\end{abstract}


PROFESI (Profesional Islam): Media Publikasi Penelitian 2019; Volume 17; No 1.

Website: ejournal.stikespku.ac.id

\section{PENDAHULUAN}

Salah satu faktor yang mempengaruhi tumbuh kembang anak adalah saat tidur dan istirahat, karena pada saat anak tidur pertumbuhan otaknya mencapai pertumbuhan yang optimal. Selain itu saat tidur pertumbuhan otak mencapai puncaknya dan hormone pertumbuhan diproduksi tiga kali lebih banyak dibandingkan pada saat bangun. Tidur merupakan prioritas utama bagi bayi, karena pada saat inilah terjadi repair neuro brain dan kurang lebih $75 \%$ hormon pertumbuhan diproduksi oleh karenanya, kualitas dan kuantitas tidur bayi perlu dijaga. Kualitas dan kuantitas tidur buah hati dapat dilihat dari cara tidurnya, kenyamanan tidur dan pola tidur. Tercapainya pertumbuhan dan perkembangan anak yang optimal merupakan hasil interaksi berbagai faktor yang saling berkaitan, yantiu faktor genetik, lingkungan, perilaku, rangsangan atau stimulasi yang bermanfaat. Anak yang sering mendapatkan stimulasi akan terarah dan lebih cepat berkembang dibandingkan anak yang kurang atau yang tidak mendapatkan stimulasi. Stimulasi adalah suatu perangsangan yang datang dari lingkungan luar anak, yang berupa stimulasi verbal, stimulasivisual, stimulasi auditif dan taktil (sentuhan). Salah satu stimulasi berupa taktil adalah pemijatan pada anak (baby massage). Baby massage (pijat bayi) merupakan salah satu stimulasi yang dilakukan dengan usapan halus pada permukaan kulit bayi, dilakukan dengan tangan bertujuan untuk menghasilkan efek terhadap otot, sistem pernafasan, saraf serta sirkuasi darah dan limpa (Subakti, 2018).

Pijat bayi merupakan pengungkapan rasa kasih sayang antara orang tua dengan anak lewat sentuhan pada kulit. Sentuhan dan pelukan seorang ibu merupakan kebutuhan dasar bayi. Dimana semua itu memiliki dampak yang luar biasa bagi perkembangan bayi. Sentuhan yang dihadirkan dalam pijatan-pijatan lembut untuk bayi merupakan sebuah stimulasi yang penting dalam tumbuh kembang anak. Anak yang mendapat stimulus terarah dan teratur akan lebih cepat berkembang dibandingkan dengan anak yang kurang atau tidak mendapat stimulus. (Syaukani, 2015).
Pijat bayi yang dilakukan bermanfaat untuk mengurangi masalah pada anak, seperti susah tidur, berat badan kurang/ tidak meningkat, sakit persendian, gangguan dalam perkembangan dan lain-lain. Pijat dikatakan mempunyai efek positif pada kesehatan bayi, karena berpengaruh terhadap kerja nervus vagus sehingga memperbaiki motilitas saluran cerna termasuk pengosongan lambung. Keadaan tersebut menyebabkan absopsi makanan dan kualitas tidur yang lebih baik.

Pijat juga dapat bermanfaat untuk memenuh waktu tidur dan perkembangan bayi. Bayi yang dipijat akan dapat tidur dengan lelap, sedangkan pada waktu bangun, daya konsentrasinya akan lebih penuh (Roesli, 2013). Selama fase bayi, pertumbuhan sel-sel syaraf belum sempurna sehingga diperlukan waktu tidur yang lebih lama untuk perkembangan syaraf, pembentukan sinaps dan sebagainya. Otak bayi tumbuh 3 kali lipat dari keadaan saat lahir atau $80 \%$ dari otak orang dewasa di tahun pertamanya. Kondisi ini hanya terjadi satu kali saja seumur hidup. Sehingga untuk tumbuh kembang yang maksimal bayi membutuhkan waktu tidur yang cukup.

Pada saat tidur tubuh bayi memproduksi hormon pertumbuhan tiga kali lebih banyak dibandingkan ketika bayi terbangun, tetapi masih banyak bayi yang mengalami gangguan tidur (Vina, 2010 dalam Minarti 2012). Kebutuhan tidur tidak hanya dilihat dari aspek kuantitas saja namun juga kualitasnya. Dengan kualitas tidur yang baik, pertumbuhan dan perkembangan bayi dapat dicapai secara optimal (Widiyanti $d k k$, 2008).

Menurut hasil penelitian Sekartini tahun 2010, yang dilakukan di 5 kota yaitu Jakarta, Bandung, Medan, Palembang dan Batam dengan jumlah responden 385 orang, diperoleh data $51,3 \%$ bayi mengalami gangguan tidur, $42 \%$ jam tidur malamnya kurang dari 9 jam, terbangun malam hari lebih dari tiga kali dan lama terbangun pada malam hari lebih dari satu jam. Bayi usia 3-6 bulan normalnya tidur 15 jam/hari, 9 jam pada malam hari dan 6 jam siang hari, terbangun ditengah malam 2-3 kali.

Berdasarkan studi pendahuluan yang dilakukan di baby smile Karanganyar tahun 2019, 6 
PROFESI (Profesional Islam): Media Publikasi Penelitian 2019; Volume 17; No 1.

Website: ejournal.stikespku.ac.id

orangtua dari bayi berusia 3 - 12 bulan, diperoleh data 5 bayi dengan riwayat kualitas tidur buruk dan 1 bayi dengan kualitas tidur cukup. Setelah di lakukan massage, pola tidur bayi mengalami perubahan yang lebih baik dibandingkan pola tidur bayi sebelum di lakukan massage (data primer, 2019). Penelitian ini bertujuan untuk mengetahui pengaruh loving touch baby massage terhadap pola tidur batita.

\section{METODE PENELITIAN}

Jenis design penelitian ini yaitu one group pre test dan post test dengan pendekatan cross sectional. Tempat penelitian ini di Baby Smile Karanganyar pada bulan Mei sampai Agustus 2019 dengan jumlah sampel 50 batita dengan teknik purposive sampling. Instrumen yang digunakan dalam pengumpulan data lembar kuesioner tentang massage dan koesioner tentang pola tidur batita. Analisis data diolah secara bivariate untuk memperoleh pengaruh loving touch baby massage terhadap pola tidur batita. Untuk pengaruh massage terhadap waktu tidur siang dan malam batita menggunakan uji Wilcoxon karena terdistribusi tidak normal dan untuk mengetahui pengaruh massage terhadap kualitas tidur batita menggunakan uji Mc Namar.

Penelitian ini telah mendapatkan perijinan dari komite etik penelitian kesehatan ITS PKU Muhammadiyah Surakarta dengan No. 07/O.09/ KEPK-LPPM.ITS.PKU/V/2019. Selain itu, sebelum pelaksanaan penelitian, peneliti menjelaskan prosedur penelitian kepada sampel dan telah mendapatkan persetujuan melalui penandatanganan informed consent dari masing-masing sampel.

\section{HASIL DAN PEMBAHASAN}

a. Hasil

\section{1) Karakteristik Responden Penelitian}

Tabel 1. Jenis Kelamin responden

\begin{tabular}{lll}
\hline \multicolumn{1}{c}{ Jenis Kelamin } & F & \multicolumn{1}{c}{$\%$} \\
\hline Laki-laki & 28 & 56 \\
Perempuan & 22 & 44 \\
Total & 50 & 100 \\
\hline
\end{tabular}

Berdasarkan tabel 1 distribusi tentang jenis kelamin batita mayoritas adalah laki-laki yaitu sebanyak $56 \%$.

Tabel 2. Umur Responden

\begin{tabular}{lll}
\hline \multicolumn{1}{c}{ Umur } & \multicolumn{1}{c}{$\mathrm{N}$} & \multicolumn{1}{c}{$\%$} \\
\hline 3 bulan -1 tahun & 32 & 64 \\
$>1$ tahun -3 tahun & 18 & 36 \\
Total & 50 & 100 \\
\hline
\end{tabular}

Berdasarkan tabel 2, distribusi tentang umur batita mayoritas adalah 3 bulan sampai dengan 1 tahun yaitu sebanyak $64 \%$.

\section{2) Variabel penelitian}

Tabel 3. Pengaruh Massage Batita Terhadap Rata-Rata Waktu Tidur Siang

\begin{tabular}{lrrr}
\hline & \multicolumn{2}{c}{ Tidur Siang } & \multirow{2}{*}{$\mathrm{p}^{*}$} \\
\cline { 2 - 3 } & \multicolumn{1}{c}{ Sebelum } & \multicolumn{1}{c}{ Sesudah } & \\
\hline $\begin{array}{l}\text { Waktu } \\
\text { (Jam) }\end{array}$ & $1.29 \pm 0.62$ & $2.42 \pm 0.64$ & 0,000
\end{tabular}

Keterangan *: Uji Wilcoxon (Data Numerik Tidak Berdistribusi Normal)

Berdasarkan tabel 3, diketahui sebelum di pijat waktu tidur anak rata-rata $1.29 \pm 0.62$ jam, kemudian setelah dipijat waktu tidur siang ratarata $2.42 \pm 0.64$ jam, dengan demikian anda peningkatan lama tidur siang selama 1,13 jam atau lama tidur siang meningkat sebesar $87,6 \%$. Hasil uji Wilcoxon mendapatkan nilai $\mathrm{p}=0,000(\mathrm{p}<0,05)$ yang berarti bahwa terdapat perbedaan yang signifikan waktu tidur suang sebelum dan sesudah dipijat, dengan demikian terapi pijat anak berpengaruh terhadap lama waktu tidur siang. 
PROFESI (Profesional Islam): Media Publikasi Penelitian 2019; Volume 17; No 1.

Website: ejournal.stikespku.ac.id

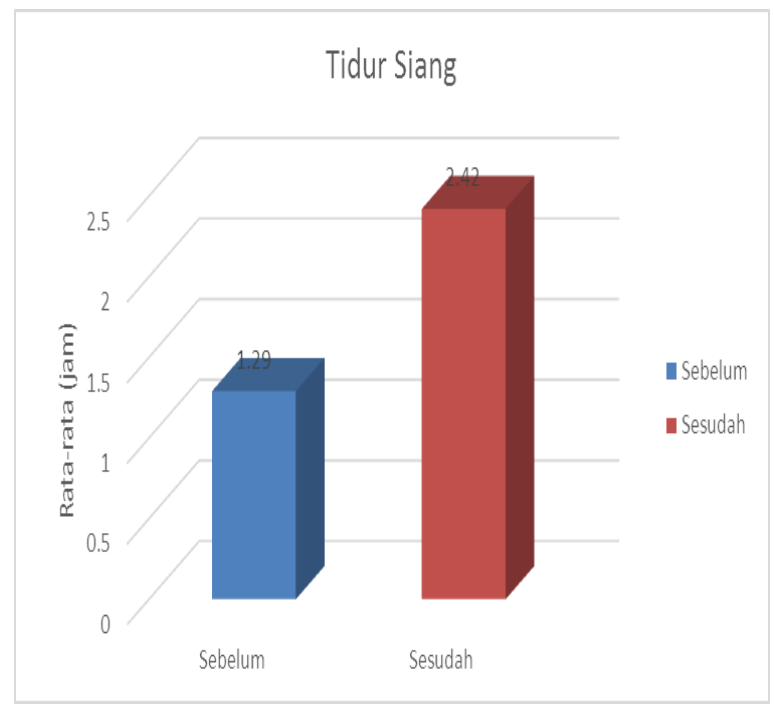

Gambar 1. Diagram Batang Perbandingan Tidur Siang Batita Sebelum dan Sesudah Dilakukan Massage

Tabel 4. Pengaruh Massage Batita Terhadap Rata-Rata Waktu Tidur Malam

\begin{tabular}{|c|c|c|c|}
\hline & \multicolumn{2}{|c|}{ Tidur Malam } & \multirow{2}{*}{$\mathrm{p}^{*}$} \\
\hline & Sebelum & Sesudah & \\
\hline $\begin{array}{l}\text { Waktu } \\
\text { (Jam) }\end{array}$ & $7.96 \pm 0.70$ & $8.90 \pm 0.93$ & 0,000 \\
\hline
\end{tabular}

Keterangan *: Uji Wilcoxon (Data Numerik Tidak Berdistribusi Normal)

Berdasarkan tabel 4, diketahui sebelum di pijat waktu tidur malam anak rata-rata $7.96 \pm 0.70$ jam, kemudian setelah dipijat waktu tidur malam rata-rata $8.90 \pm 0.93$ jam, dengan demikian anda peningkatan lama tidur malam selama 0,94 jam atau lama tidur malam meningkat sebesar $11,8 \%$. Hasil uji Wilcoxon mendapatkan nilai $\mathrm{p}=0,000$ $(\mathrm{p}<0,05)$ yang berarti bahwa terdapat perbedaan yang signifikan waktu tidur malam sebelum dan sesudah dipijat, dengan demikian terapi pijat anak berpengaruh terhadap lama waktu tidur malam.

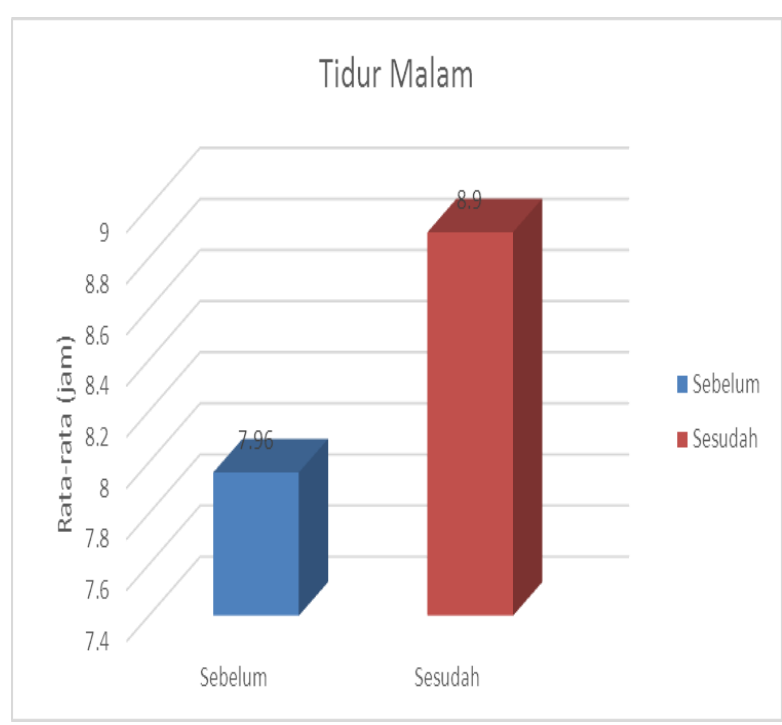

Gambar 2. Diagram Batang Perbandingan Tidur Malam Batita Sebelum dan Sesudah Dilakukan Massage

Tabel 5. Pengaruh Massage Terhadap Kualitas Tidur Batita

\begin{tabular}{lrrr}
\hline & \multicolumn{2}{c}{ Kualitas Tidur } & \multirow{2}{*}{ p $^{*}$} \\
\cline { 2 - 3 } & Sebelum & \multicolumn{1}{c}{ Sesudah } & \\
\hline $\begin{array}{l}\text { Nyenyak } \\
\text { Tidak }\end{array}$ & $8(16,0 \%)$ & $50(100,0 \%)$ & 0,000 \\
Nyenyak & $42(84,0 \%)$ & $0(0.0 \%)$ & \\
$\begin{array}{l}\text { Keterangan *: Uji } \text { mcNemar } \text { (Data Kategorik } \\
\text { Nominal) }\end{array}$ & & & \\
\end{tabular}

Berdasarkan tabel 5, diketahui sebelum di pijat kualitas tidur anak sebagian besar tidak nyenyak yaitu ada 42 anak (84,0\%), kemudian setelah dipijat kualitas tidur anak semuanya nyenyak yaitu 50 anak $(100,0 \%)$, dengan demikian anda peningkatan kualitas tidur anak setelah pemijatan. Hasil uji mcNemar mendapatkan nilai $\mathrm{p}=0,000 \quad(\mathrm{p}<0,05)$ yang berarti bahwa terdapat perbedaan yang signifikan kualitas tidur sebelum dan sesudah dipijat, dengan demikian terapi pijat anak berpengaruh terhadap kualtias tidur. 


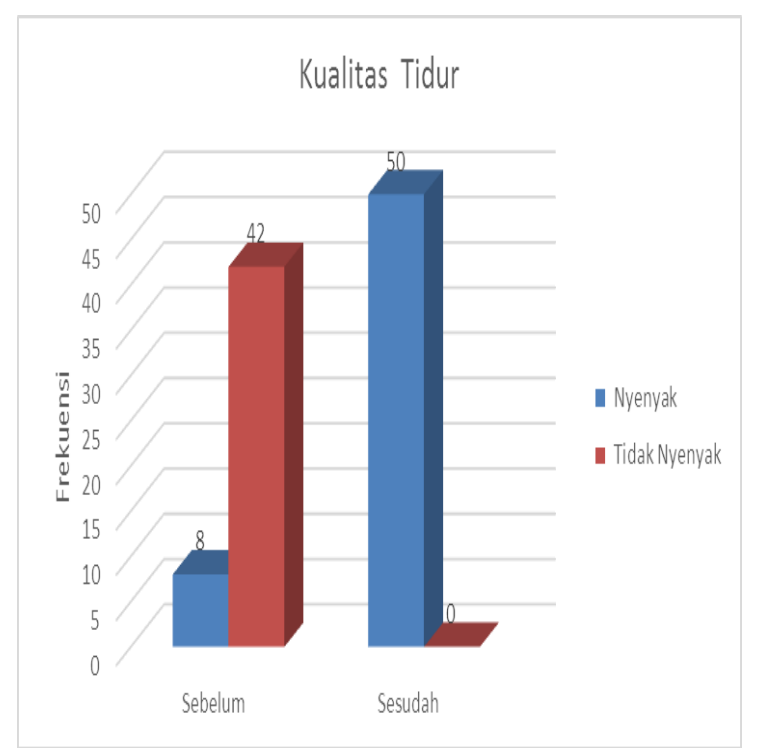

Gambar 3. Diagram Batang Perbandingan

Kualitas Tidur Batita Sebelum dan Sesudah Dilakukan Massage

\section{b. Pembahasan}

Massage merupakan salah satu bentuk dari terapi sentuh yang berfungsi sebagai salah satu teknik pengobatan penting. Massage pada anak sangatlah penting. Menurut beberapa penelitian, massage pada anak secara rutin akan membantu tumbuh kembang fisik, emosi dan pertahanan kesehatannya.

Umumnya bayi yang mendapat pijatan secara teratur lebih rileks dan tenang. Dengan sirkulasi darah dan oksigen yang lancar otomatis membuat imunitas tubuh bayi lebih baik. Bukan hanya secara fisik, pijat juga sangat mempengaruhi emosional, Karena aktivitas pijat akan menjalin bonding antara anak dan orang tua. Unsur utama pijat bayi adalah sentuhan.

Massage juga merupakan salah satu terapi non farmakologis untuk mengatasi masalah tidur bayi adalah pijat bayi (Liaw, 2000 dalam Hikmah, 2010). Massage bermanfaat untuk meningkatkan konsentrasi bayi dan membuat bayi tidur lelap.

Bayi dengan kualitas tidur yang baik akan memberikan pengaruh baik untuk kondisi fisiologis bayi. Pijat bayi merupakan sensasi sentuhan sensori yang menunjukkan bahwa sentuhan sayang dan pijatan membantu bayi tumbuh lebih kuat dan tidur lebih nyenyak.
Kualitas tidur bayi yang rendah ini dapat dikarenakan keletihan akibat aktivitas fisik yang dilakukan bayi selama 24 jam. Bayi yang mengalami keletihan fisik akan sulit tidur dan akan mudah rewel jika akan tidur serta dalam tidurnya bayi tidak bisa nyenyak dan mudah terbangun. Tidur yang tidak adekuat dan kualitas tidur yang buruk dapat mengakibatkan gangguan keseimbangan fisiologi dan psikologi. Menurut Perry \& Potter (2009). dampak fisiologi meliputi penurunan aktivitas seharihari, rasa capek, lemah, koordinasi neoromuskular buruk, proses penyembuhan lambat dan daya tahan tubuh menurun. Sedangkan dampak psikologinya meliputi emosi lebih labil, cemas, tidak konsentrasi, kemampuan kognitif dan menggabungkan pengalamannya lebih rendah. Selain itu kualitas tidur juga dipengaruhi oleh beberapa faktor. Diantara yang dapat mempengaruhinya yaitu lingkungan. Keadaan lingkungan yang aman dan nyaman bagi seseorang dapat mempercepat terjadinya proses tidur. Lingkungan fisik tempat bayi tidur berpengaruh penting pada kemampuan untuk tertidur dan tetap tertidur. Nutrisi (minum atau makan) juga merupakan faktor penting, jika bayi merasa belum kenyang akan sulit tidur. Selain itu bayi sakit juga dapat mengganggu tidur bayi (Riadiani, 2010 dalam Setiawan, 2015).

Pada usia 2 sampai dengan 3 tahun, anakanak biasa nya tidur sepanjang malam dan tidur siang setiap hari. Total tidur rata-rata 12 jam perhari. Tidur siang dapat hilang pada usia 3 tahun. Hal yang umum bagi todler terbagun pada malam hari. Persentasi tidur REM berlanjut menurun selama periode ini todler tidak ingin tidur pada malam hari ketidakinginan ini dapat berhubungan dengan kebutuhan untuk otonomi, atau takut perpisahaan. Todler mempunyai kebutuhan untuk mengeksplorasi dan memuaskan keingin tahuannya, yang dapat menjelaskan mengapa beberapa dari mereka mencoba untuk menunda waktu tidur.

Tidur nyenyak sangat penting bagi pertumbuhan anak, karena saat tidur pertumbuhan otak anak mencapai puncaknya. Selain itu pada saat tidur tubuh anak memproduksi hormon pertumbuhan tiga kali lebih banyak dibandingkan ketika 
PROFESI (Profesional Islam): Media Publikasi Penelitian 2019; Volume 17; No 1.

Website: ejournal.stikespku.ac.id

anak terbangun (Gola, 2009). Namun kenyataannya dalam suatu penelitian ditemukan $51,3 \%$ bayi mengalami gangguan tidur, $42 \%$ anak tidur malam dan tidur siangnya. Salah satu cara untuk mengatasi masalah tidur balita adalah dengan pijat bayi. Pijat bayi yang dilakukan untuk mengurangi masalah pada anak, seperti susah tidur, berat badan kurang/ tidak meningkat, sakit persendian, gangguan dalam perkembangan dan lain-lain.

Berdasarkan hasil penelitian yang telah dilakukan didapatkan bahwa batita yang telah dilakukan massage waktu tidur siang dan tidur malamnya menjadi lebih lama dibandingkan sebelum dilakukan massage. Sehingga dari hasil analisis didapatkan bahwa nilai nilai $\mathrm{p}=0,000$ $(p<0,05)$ yang berarti bahwa terdapat pengaruh yang signifikan waktu tidur siang dan tidur malam sebelum dan sesudah dilakukan massage.

Hal ini sesuai dengan penelitian yang telah dilakukan oleh Bennet et al (2013) yang berjudul Massage For Promoting Mental And Physical Health In Typically Developing Infants Under The Age Of Six Months menunjukkan berbagai manfaat pijat bayi terhadap perkembangan bayi baik dari segi fisik maupun mental. Penelitian ini menyimpulkan bahwa pemberian pijat bayi berdampak pada peningkatan pola tidur bayi, system pernafasan bayi serta meningkatkan pertumbuhan bayi. Pemberian pijat bayi juga menurunkan tingkat stres bayi yang disebabkan adanya intensitas sentuhan bayi dengan orang tua. Underdown (2013) mengemukakan bahwa salah satu sisi positif dalam pemberian pijat bayi adalah adanya interaksi atau hubungan ibu dengan bayi yang lebih intensif. Penelitian secara sistematis yang dilakukan termasuk terhadap 34 uji coba terkontrol secara acak menemukan bukti efektivitas pijat bayi pada peningkatan pertumbuhan bayi usia enam bulan kebawah. Namun dalam penelitian ini memberikan rekomendasi bahwa pemberian pijat bayi belum teruji kepada kelompok bayi yang memiliki resiko tinggi.

Berdasarkan penelitian ini dari hasil analisis tentang kualitas tidur batita, didapatkan bahwa batita yang telah dilakukan massage mengalami kualitas tidur yang lebih baik dibandingkan sebelum di lakukan massage. Hasil analisis diperoleh nilai $\mathrm{p}=0,000 \quad(\mathrm{p}<0,05)$ yang berarti bahwa terdapat perbedaan yang signifikan kualitas tidur sebelum dan sesudah dilakukan massage.

Kualitas tidur adalah mutu atau keadaan fisiologis tertentu yang didapatkan selama seseorang tidur, yang memulihkan proses-proses tubuh yang terjadi pada waktu orang itu bangun. Jika kualitas tidurnya bagus artinya fisiologi tubuh dalam hal ini sel otak misalnya pulih kembali seperti semula saat bangun tidur. Kualitas tidur yang baik ditunjukan dengan jumlah jam tidur bayi yang cukup, bayi dapat jatuh tertidur dengan mudah di malam hari, bugar saat bangun tidur, dan tidak rewel.

Hasil penelitian ini sesuai dengan penelitian yang dilakukan di Touch Research Institute Amerika yang menunjukkan bahwa anak-anak yang dipijat selama $2 \times 15$ menit setiap minggunya dalam jangka waktu 4 minggu, tidurnya menjadi lebih nyenyak sehingga pada waktu bangun konsentrasinya lebih baik daripada sebelum diberi pemijatan (Roesli, 2013).

Penelitian lain dilakukan oleh Roth (2012) tentang the relationship massage infant with pattern and sleep in infants. Penelitian ini menyimpulkan bahwa sentuhan-sentuhan yang diberikan pada saat pijat bayi memiliki hubungan dengan peningkatan kualitas tidur bayi yang ditunjukkan dengan peningkatan jumlah durasi tidur bayi serta berkurangnya gangguan tidur bayi. Peningkatan kuantitas tidur pada bayi yang diberi pemijatan tersebut disebabkan oleh adanya peningkatan kadar sekresi serotonin yang dihasilkan pada saat pemijatan, disamping itu pada pemijatan juga terdapat perubahan gelombang otak yaitu terjadinya penurunan gelombang alpha dan peningkatan gelombang beta serta theta yang dapat dilihat melalui penggunaan EEG (Elektroensefalografi) (Roesli, 2013). Serotonin merupakan zat transmitter utama yang menyertai pembentukan tidur dengan menekan aktivitas sistem pengaktivasi retikularis maupun aktivitas otak lainnya. Mas'ud (2008), serotonin yang disintesis dari asam amino tripthophan akan diubah menjadi 5-hidroksitriptophan (5HTP) kemudian 
PROFESI (Profesional Islam): Media Publikasi Penelitian 2019; Volume 17; No 1.

Website: ejournal.stikespku.ac.id

menjadi $\mathrm{N}$-asetil serotonin yang pada akhirnya berubah menjadi melatonin. Melatonin mempunyai peran dalam tidur dan membuat tidur lebih lama dan lelap pada saat malam hari. Hal ini sesuai dengan pendapat Roesli (2013) bahwa pemijatan dapat meningkatkan kadar serotonin yang akan menghasilkan melatonin yang berperan dalam tidur dan membuat tidur lebih lama dan lelap pada malam hari. Serotonin juga akan meningkatkan kapasitas sel reseptor yang berfungsi mengikat glukokortikoid (adrenalin, suatu hormon stress). Proses ini menyebabkan terjadinya penurunan kadar hormon adrenalin (hormon stress) sehingga bayi yang diberi perlakuan pemijatan akan tampak lebih tenang dan tidak rewel. Pemijatan juga meningkatkan mekanisme penyerapan makanan oleh nervus vagus sehingga nafsu makan bayi juga meningkat.

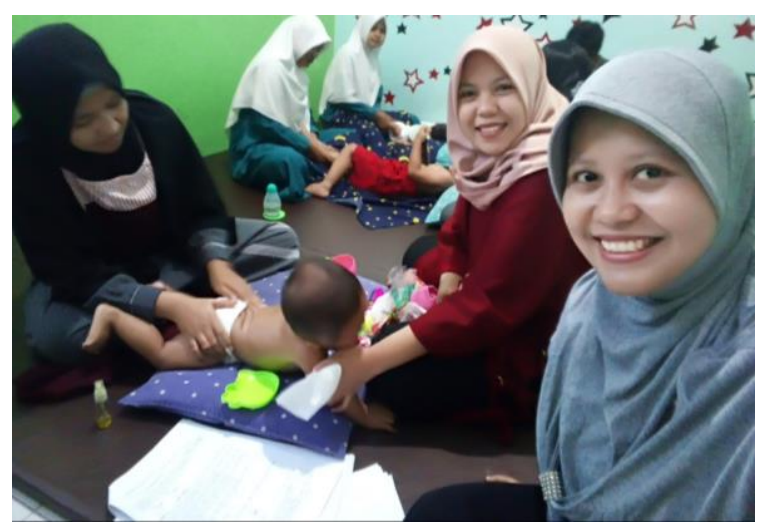

Gambar 4. Pengambilan data pada saat penelitian berlangsung

\section{SIMPULAN}

\section{a. Kesimpulan}

Karakteristik responden berdasarkan jenis kelamin batita mayoritas adalah laki-laki yaitu sebanyak $64 \%$ dari 50 batita dan karakteristik responden berdasarkan umur mayoritas adalah laki-laki sebanyak $56 \%$.

Batita yang telah dilakukan massage mengalami perubahan pola tidur baik kuantitas tidur ataupun kualitas tidur dibandingkan batita sebelum dilakukan massage. Sehingga bisa disimpulkan bahwa ada pengaruh yang signifikan loving touch massage terhadap pola tidur batita.

\section{b. Saran}

Bagi peneliti selanjutnya diharapkan dapat melakukan penelitian dengan varibel bebas yang lebih lengkap terkait faktor-faktor massage dan perkembangan batita.

\section{REFERENSI}

Bennet C, Underdown A, and Barlow J. (2013). Massage For Promoting Mental And Physical Health In Typically Developing Infants Under The Age Of Six Months. Article Review. The Cochrane Collaboration. Published by JohnWiley \& Sons, Ltd.

Gola, G. (2009). Ayo Bangun! Dengan Bugar Karena Tidur Yang Benar. Jakarta : Hikmah.

Hikmah, Ema. (2010). Pengaruh Terapi Sentuhan Terhadap Suhu Dan Frekuensi Nadi Bayi Prematur Yang Dirawat Di Ruang Perinatologi RSUD Kabupaten Tangerang. Thesis. Depok : Fakultas Ilmu Keperawatan Kekhususan Keperawatan Anak Universitas Indonesia.

Mas'ud, I. (2008). Fisiologi :Persepsi Kerja Otak. Malang :UM Press Malang

Minarti. (2012). Pengaruh Pijat Bayi Terhadap Kualitas Tidur Bayi USIA 3-6 Bulan Di Wilayah Kerja Puskesmas II Denpasar Timur. Jurnal. Alamat unduhan http://ojs.unud.ac.id/index.php/coping/art icle/download/6466/4981. Diakses pada tanggal 25 Juli 2019

Perry, A.G.,\& Potter, P. A. (2009). Buku Ajar Fundamental Keperawatan. Edisi 4 Volume 1 dan 2. Jakarta: EGC.

Roesli. (2013). Pedoman Pijat Bayi. Edisi Revisi. Jakarta: Trubus Agriwidya.

Roth, DE. (2012). The Relationship Massage Infant With Pattern And Sleep In Infants. journal of pediatric: The University of Toledo Digital Repository 
PROFESI (Profesional Islam): Media Publikasi Penelitian 2019; Volume 17; No 1.

Website: ejournal.stikespku.ac.id

Setiawan. (2015). Pemberian Terapi Pijat Bayi Terhadap Kualitas Tidur Bayi Pada Asuhan Keperawatan An.N Dengan Infeksi Saluran Pernafasan Akut Di Ruang Melati RSUD Karanganyar. Thesis. Surakarta: STIKES Kusuma Husada.

Subakti, Y. A. (2018). Keajaiban Pijat Bayi dan Balita. Jakarta: PT Wahyu Media.

Syaukani. (2015). Petunjuk Praktis Pijat Senam dan Yoga Sehat Untuk Bayi. Araska: Yogyakarta
Underdown, A. (2013). Infant Massage as a Community Intervention for Infants aged under 6 month. Journal of Pediatric. Frances Bunn, University of Hertfordshire.

Widiyanti, M. dkk. (2008). Hubungan Pijat Bayi Dengan Pola Tidur Bayi Usia 3 -6 Bulan Di Bidan Praktek Swasta. Skripsi. Poltekes Depkes: Malang 